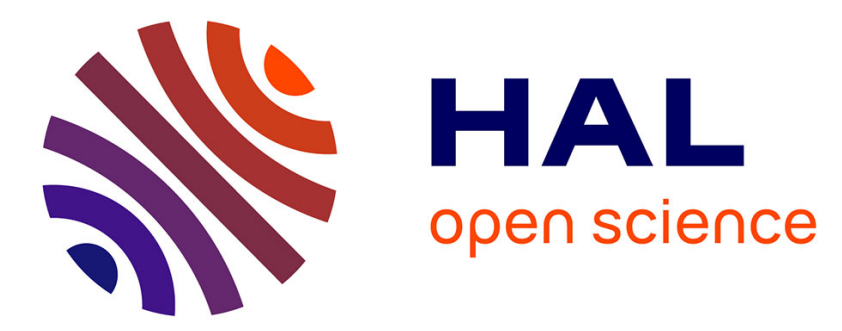

\title{
20th anniversary of the medical image analysis journal (MedIA)
}

Nicholas Ayache, James Duncan

\section{To cite this version:}

Nicholas Ayache, James Duncan. 20th anniversary of the medical image analysis journal (MedIA).

Medical Image Analysis, 2016, 33, pp.1-3. 10.1016/j.media.2016.07.004 hal-01353697

\section{HAL Id: hal-01353697 \\ https://hal.inria.fr/hal-01353697}

Submitted on 12 Aug 2016

HAL is a multi-disciplinary open access archive for the deposit and dissemination of scientific research documents, whether they are published or not. The documents may come from teaching and research institutions in France or abroad, or from public or private research centers.
L'archive ouverte pluridisciplinaire HAL, est destinée au dépôt et à la diffusion de documents scientifiques de niveau recherche, publiés ou non, émanant des établissements d'enseignement et de recherche français ou étrangers, des laboratoires publics ou privés. 


\section{0th anniversary of the medical image analysis journal (MedIA)}

This special issue of Medical Image Analysis gathers 32 articles written by prominent members of the current editorial board of the journal. Each author had the opportunity to discuss a personal vision of the past and future of the field. The result is a set of outstanding visionary articles that will count as a historical landmark for our readership.

It was shortly after the success of the first CVRMed conference ${ }^{1}$ held in Nice in 1995 that we took the decision to launch a new journal entirely dedicated to the computational analysis of medical images. The founding editorial board members ${ }^{2}$ of MedIA were among the authors of the articles of the first volume $^{3}$ of the journal published by Oxford University Press in 1996.

Twenty years later, the journal (now published by Elsevier Science since 2000) has become a reference for a vibrant community of researchers working in academics, clinics and industry. It has also become the premier journal of the MICCAI Society, which organizes the Medical Image Computing and Computer Assisted Intervention conference each year on a different continent.

Medical Image Analysis is now recognized as a flourishing research field at the intersection of Informatics, Computational Sciences and Medicine. Its progress contributes to the development of innovative computational tools to assist medical imaging professionals in clinical analysis and intervention.

It has been our pleasure to serve this journal and this research community from its origin; we look forward to continue serving both in the future.

21 June 2016

Nicholas Ayache (Nice, France) \& James Duncan (New Haven, USA)

Co-Editors-in-Chief, Medical Image Analysis

\section{References}

Nicholas Ayache. Medical Imaging Informatics: Towards a Personalized Computational Patient. IMIA Yearbook of Medical Informatics, May 2016. Open access at DOI: http://dx.doi.org/10.15265/IYS- 2016- s002

N. Paragios, J. Duncan, N. Ayache. Handbook of Biomedical Imaging: Methodologies and Clinical Research. Springer, 2015. 
Ayache, M. Brady, D. Comaniciu, A. Criminisi, J. Duncan, O. Faugeras, G. Gerig, D. Hawkes, P. Hunter, N. Navab \& D. Rueckert: http://www.college-de-france.fr/site/en- nicholas- ayache/symposium- 2013-2014.htm

The Personalized Digital Patient: Images, Medicine and Informatics, April-June 2014: Videos and slides of 16 lectures by J. Marescaux, M. Haïssaguerre, JF. Mangin, H. Delingette, B. Thirion, X. Pennec, S. Lehéricy, C. Barillot, E. Mandonnet, J. Troccaz, JP. Galmiche, S.Loiseau, P. Jaïs, JF. Gerbeau, L. Soler \& S. Cotin: http://www.college- de-france.fr/site/ennicholas- ayache/seminar-2013-2014.htm and 8 courses by N. Ayache: http://www.college-de-france.fr/site/nicholasayache/_course.htm (in French) http://www.college-de-france.fr/site/en- nicholas-ayache/course-2013-2014.htm (in English).

N. Ayache, From Medical Imaging to the Digital Patient, 10 April 2014: Video and slides of Inaugural Lecture at College de France http://www.college- de-france.fr/site/nicholas- ayache/inaugural- lecture- 2014-04-10-18h00.htm (in French) http://www.college-de-france.fr/site/en- nicholas- ayache/inaugural-lecture- 2014-04- 10-18h00.htm (in English)

J. Duncan \& N. Ayache, Medical Image Analysis: Progress over Two Decades and the Challenges Ahead. IEEE Transactions on Pattern Analysis and Machine Intelligence, Volume 22 Issue 1, January 200 0, 85-106. 